DOI: http://doi.org/10.22364/cl.69.10

\title{
KOGNITĪVĀ RELIĢIJAS ZINĀTNE UN RELIĢISKO TICĪBU PAMATOTĪBAS DEBATES
}

Normunds Titāns

Dr. phil., LU Teologijas fakultātes profesors

\section{Ievads: kognitīvā religijias zinātne, tās ambīcijas un loma relig̣ijas diskreditēšanā}

Reliǵijas $^{1}$ un reliğisku fenomenu rašanās un pastāvēšanas izskaidrošanai ar "dabiskiem" (piem., psihologiskiem, sociāliem, funkcionāliem u. c.) faktoriem ir iespaidīga teorētiskā vēsture 19. gadsimta otrajā pusē un 20. gadsimta pirmajā pusē, it īpaši pēc bioloğiskās evolūcijas teorijas ieviešanās un tās tālākas piemērošanas arī sabiedrību attīstības interpretācijā. ${ }^{2}$ Pēc tam seko kādu pusgadsimtu ilgs salīdzinoši klusāks periods, kad šajā jomā nenotiek vismaz nekādi sensacionāli jaunatklājumi, bet tad pēc kāda laika, 20. gadsimta otrajā pusē, un it īpaši beigās, religijijas zinātniskā izpēte un interpretācija atdzimst ar jaunu un vēl nebijušu sparu, kas nav norimis vēl tagad. Šì jaunā elpa relig̣ijas zinātniskajā pētniecībā saistās ar jaunas zinātnes - kognitīvās zinātnes - uzplaukumu 20. gadsimta otrajā pusē.

1 Varētu diskutēt, vai pastāv reliğija vienskaitlī, vai arī ir tikai konkrētas reliğijas. Šo diskusiju šeit neizvērsīšu, bet šeit un turpmāk izmantošu vārdu "religija" modernajā laikā jau ierastā lietojumā - kā sugas vārdu, kas aptver dažādo konkrēto religijiju klases.

2 Ietekmīgas un vēl joprojām interesanti lasāmas religijas izskaidrojuma teorijas šajā laika posmā izstrādājuši tādi domātāji kā Ludvigs Feierbahs (1804-1872), Kārlis Markss (1818-1883) un Frīdrihs Engelss (1820-1895), Eduards Tailors (Edward Tylor, 1832-1917), Emīls Dirkems (Émile Durkheim, 1858-1917), Džeimss Freizers (James Frazer, 1854-1941), Zigmunds Freids (1856-1939) u. c. 
Kā jau prima facie norāda pats jēdziens "kognitīvs" ${ }^{3}$ vārdkopā "kognitīvā zinātne", tā ir zinātne, kas pēta to, kā notiek pati zināšana, pateicoties cilvēka kognitīvajām jeb prāta funkcijām. Kognitīvās zinātnes pētniecības tematikā ietilpst tādi kognitīvie procesi kā valoda, domāšana, saprašana, spriešana, uztvere, uzmanība, atmiņa, konceptualizēšana, komunikācija, mācīšanās, izlemšana, iztēle, emocijas utt., kuri savstarpēji mijiedarbojas. Turklāt nav vienas kognitīvās zinātnes. Tā ir multidisciplināra zinātne, kurā gan atsevišķi darbojas, gan konverğē vairākas zinātņu jomas, piemēram, psiholog̣ija (ieskaitot tādas psihologijijas apakšnozares kā kognitīvā psihologija, neiropsiholog̣ija, evolucionārā psihologijija u. c.), smadzeņu zinātne (brain science), neirozinātne, antropologija (ieskaitot kultūras antropolog̣iju un sociālo antropologijiju, kā arī arheologiju), filozofija (ieskaitot epistemolog̣iju un prāta filozofiju [philosophy of mind]), datorzinātne (ieskaitot mākslīgā intelekta izveides pētniecību), matemātika (ieskaitot tās pielietojumu skaitḷošanas prāta teorijā [computational theory of mind]), lingvistika (ieskaitot neirolingvistiku un psiholingvistiku) u. c.

Tāpat kā jebkurās citās cilvēka kulturālās un sabiedriskās izpausmēs, arī religijijās, to tapšanā un praktizēšanā dažādos veidos darbojušies un darbojas visi kognitīvie procesi, ieskaitot iepriekš uzskaitītos. Iespējams, ka tieši reliğisko izpausmju daudzveidīguma dēḷ tās kḷūst par izdevīgu izmēǵinājuma lauku kognitīvo zinātņu teoriju testēšanai. Attiecīgi 20. gadsimta beigās radās kognitīvās zinātnes apakšnozare kognitīvā reliǵijas zinātne (turpmāk tekstā KRZ, angliski CSR - Cognitive Science of Religion). Tā ir zinātne, kurā dažādu kognitīvās zinātnes empīrisko un teorētisko disciplīnu pārstāvji skaidro religisiskās ticības un prakses ar cilvēkiem universāli piemītošu kognitīvo struktūru funkcionēšanu. KRZ perspektīvā reliğiskie priekšstati, pārliecības, institūcijas, sistēmas, prakses, uzvedības, pieredzes un citi reliǵgiski fenomeni ir radušies, darbojas, tiek uzturēti un nodoti tālāk, pateicoties neapzinātu kognitīvu mehānismu darbībai. Šie mehānismi darbojas dabiski un pastāvīgi, jo tie ir genētiski ieprogrammēti mūsu smadzenēs evolūcijas atlases adaptīvajā procesā. Reliǵija

Jēdziens nāk no latīnuu valodas vārda cognoscere - uzzināt (sakne radniecīga arī grieķu vārdam gnōsis - zināšana). 
pat nav šo mehānismu ekskluzīvā īstenošanās sfēra. Tie darbojas arī citos cilvēku ikdienas dzīves un saskarsmes kontekstos. Reliǵiskie fenomeni KRZ drīzāk tiek saredzēti kā šo mehānismu funkcionēšanas "blakusprodukti".

Metodologiiski KRZ lielā mērā balstās vismaz uz diviem pieņēmumiem ar nozīmīgām sekām attieksmē pret relig̣iju. Pirmkārt, pretēji pašu reliǵiozo cilvēku domām, reliǵijai kultūras izteiksmju vidū nav unikāla sui generis statusa, tāpēc tā jāpēta un jāizskaidro tāpat kā jebkura cita kultūras izteiksme. Otrkārt, šajā pētniecībā jāpieņem metodoloǵisks naturālisms, neatzīstot, ka relig̣ijas skaidrojumiem "no iekšienes" var būt kāda vērā ņemama un ticama izskaidrojuma vērtība. ${ }^{4}$

Mūsdienās KRZ gūst īpašu ievērību un ieņem autoritatīvu statusu reliğijpētnieku vidū varbūt daḷēji tāpēc, ka pats daudzu zinātñu nozaru starpdisciplinārās iesaistīšanās fakts piešksir ticamības auru jaunās KRZ atziņām, atradumiem, koncepcijām un teorijām. KRZ pieeju un teorijas jau kumulatīvi apzīmē kā jaundibinātu relig̣ijas saprašanas "paradigmu", uz to plaši atsaucas kā uz tagadējo reliğijas izskaidrošanas "standarta modeli". ${ }^{5}$

KRZ piesaistījusi arī lielu sabiedrisku uzmanību populārzinātniskā līmenī, jo tās atziņas skaḷi izmanto mūslaiku t. s. jaunā ateisma runasvīri, kompromitējot religisko ticību racionalitāti, pamatotību, ticamību. ${ }^{6}$ Relig̣ijas kognitīvie izskaidrojumi tiek izmantoti reliǵijas apkarošanā. No šiem izskaidrojumiem bieži vien tiek izdarīti pārlieku vienkāršoti secinājumi par reliǵijas maldību, neiesaistoties komplicētā, daudzpusīgā argumentācijā un uzklausot dažādas puses. ${ }^{7}$

Ņemot vērā KRZ stabili iekaroto statusu akadēmiskā vidē, tās teorijas nevar paslīdēt garām arī religijijas filozofu un

4 Dimitris Xygalatas, "Cognitive Science of Religion," in Encyclopedia of Psychology and Religion, ed. D. A. Leeming (Berlin, Heidelberg: Springer-Verlag, 2016), 1.

5 Tā dara daudzi. Piemēram, skat. Aaron C. T. Smith, Thinking about Religion: Extending the Cognitive Science of Religion (New York: Palgrave Macmillan, 2014), $17 \mathrm{ff}$.

6 Var minēt kaut vai t. s. jaunā ateisma četras "lokomotīves" Ričarda Dokinsa (Richard Dawkins), Kristofera Hičensa (Christopher Hitchens), Daniela Deneta (Daniel Dennett) un Sema Herisa (Sam Harris) personā.

7 Kaut arī tas tā nav vienmēr. Ir arī skrupulozi izstrādāti ateistiskas argumentācijas gadījumi, izmantojot KRZ. 
teologu ievērībai un analīzei, jo šīs teorijas ienes radikāli jaunu perspektīvu šo divu pēdējo jomu pārstāvju izziņas priekšmeta relig̣ijas - saprašanā. Vēl jo vairāk, vismaz teologi un teistiski orientēti religijas filozofi nespēj neko nedarìt un palikt vienaldzīgi iepriekš minēto, ar KRZ saistīto skaļo ateistisko mudinājumu un religijas izskaušanas ambīciju kontekstā. 21. gadsimtā publicēts ievērojams daudzums rakstu un grāmatu teisma filozofiskai un teologiiskai aizstāvībai pret KRZ veikto relig̣ijas "atmaskošanu" (angliski debunking). Debates joprojām turpinās. Šajā rakstā attiecīgi tiks ieskicēti galveno KRZ koncepciju raksturīgi piemēri, no KRZ teorijām atvasinātu antiteistisku argumentu piemēri un teistiski ievirzītu vai vismaz teismu nenoliedzošu atbildes argumentu piemēri.

Šis raksts būs analītisks, bez patiesības apgalvojumiem par to, kurai argumentētāju pusei ir taisnība - naturālistiem vai teistiem. Tas lai paliek katra/-s lasītāja/-s ticības jautājums.

\section{Īss ieskats KRZ koncepcijās}

\section{Kognitīvie mehānismi}

Starp KRZ celmlaužiem, pirmkārt, minams franču antropologs Dans Sperbērs (Dan Sperber), kurš pagājušā gadsimta 70. gados sāk interpretēt kultūras fenomenus ar kognitīvās pieejas palīdzību. Šajā perspektīvā viņš analizē simbolismu, ieskaitot reliǵisko simbolismu. Sperbērs iezīmē KRZ ar vairākiem savas pētniecības aspektiem. Vispirms Sperbērs atsakās no kultūras apstākḷu semiotiski nosacītām simbolu interpretācijām par labu universāliem skaidrojumiem, kas balstās uz prāta arhitektūru ("simboliskiem mehānismiem”). ${ }^{8}$ Vēl svarīgāk, kā tas ir raksturīgi kognitīvajai zinātnei, Sperbērs uzskata, ka cilvēka prāts sastāv no evolūcijas procesā veidotām neironu struktūrām jeb "moduḷiem”, kas saistīti ar specifiskām pielietojuma jomām jeb "domēniem". ${ }^{.}$Šo teoriju Sperbērs izvērš, apgalvojot, ka kultūra visās tās dažādajās izpausmēs radusies

8 Dan Sperber, Rethinking Symbolism, trans. Alice L. Morton (Cambridge: Cambridge University Press, 1975).

9 Dan Sperber, "The Modularity of Thought and the Epidemiology of Representations," in Mapping the Mind: Domain-Specificity in Culture and Cognition, ed. L. A. Hirschfeld and S. Gelman (Cambridge: Cambridge University Press, 1994), 39-67; Dan Sperber, "In Defense of Massive Modularity," in Language, Brain and Cognitive Development: Essays 
šo kognitīvo moduḷu darbības rezultātā. ${ }^{10}$ Vēl svarīgi pieminēt, ka arī Sperbērs, mēgeinot izskaidrot, kāpēc dažas idejas kultūrā izplatās veiksmīgāk nekā citas, iekḷaujas to autoru pulkā, kas aizstāv t. s. ideju epidemiolog̣ijas tēzi, kas nozīmē, ka līdzīgi lipīgām slimībām ir arī "lipīgas idejas", ar ko smadzenes "inficējas" cita no citas. ${ }^{11}$

Reliğisko ideju tālāknodošanas teoriju paralēli aizsāk Oksfordas genētiķis un jaunā ateisma kustības trubadūrs Ričards Dokinss (Richard Dawkins). Tikai viņš teoriju skaidro ar metaforu, kas ņemta nevis no epidemiologijas, bet gan no genētikas. Dokinsam reliǵisko pārliecību izplatība sabiedrībā izskaidrojama ar replikāciju, kas līdzīga ġenētiskajai replikācijai un ko realizē vienības, kuras viņš nosauc par mēmiem (memes). Nodoms šāda termina lietošanai ir norādīt uz analog̣iju ar gēniem, bet etimologisiski tas ir saīsinājums no grieķu vārda mimēma ( $\mu i \mu \eta \mu \alpha)$, kas saistās ir imitāciju. Mēms ir kāda ideja vai uzvedības modelis, kas pāriet no personas uz personu kādā kultūrā. Mēms ir elements, ar kura starpniecību kādas kultūras idejas, simboli un prakses tiek nodotas no personas personai ar rakstiem, runu, žestiem, rituāliem u. c. imitējamām izteiksmēm. Līdzīgi gēniem, arī mēmi replicējas, konkurē dabiskās atlases procesā, piedzīvo variācijas un mutācijas, adaptējas utt. Mēmi izplatās ar uzvedības modeliem, ko tie izraisa savos nesējos. Dokinss tipiski raksta: "Tāpat kā gēni pavairo sevi genofondā, pārlecot no ķ kermeņa uz ķ่ermeni ar spermatozoīdiem vai olšūnām, tāpat arī mēmi pavairo sevi memofondā, pārlecot no smadzenēm uz smadzenēm ar tā procesa palīdzību, ko plašā šī jēdziena izpratnē var saukt par imitāciju." ${ }^{12}$

Pēc Dokinsa domām, ticība Dievam ir plaši izplatīta ne jau tāpēc, ka tāda būtne kā Dievs faktiski pastāv, un ne jau tāpēc,

in Honor of Jacques Mehler, ed. E. Dupoux (Cambridge, MA: The MIT Press, 2001), 47-57.

10 Dan Sperber, Explaining Culture: A Naturalistic Approach (Oxford: Basil Blackwell, 1996).

${ }_{11}$ Dan Sperber, "The Modularity of Thought and the Epidemiology of Representations," in Mapping the Mind: Domain-Specificity in Culture and Cognition, ed. L. A. Hirschfeld and S. Gelman (Cambridge: Cambridge University Press, 1994); Dan Sperber, Explaining Culture: A Naturalistic Approach.

12 Richard Dawkins, The Selfish Gene (New York: Oxford University Press, 1989), 192. 
ka būtu pietiekami iemesli ticēt, ka tāda būtne pastāv. Cilvēki tic tāpēc, ka cilvēkos un kultūrās līdzīgi vīrusam ir savairojies "Dieva mēms". Religija (tas pats attiecas uz visām saistītajām relig̣iskajām pārliecībām) radusies kā kḷūmīgs, nejaušs "blakusprodukts" psihologiskiem faktoriem, kas reiz evolūcijas procesā bija noderīgi. Dokinss pats min piemēru/hipotēzi par bērniem..$^{13}$ Biežāk nekā jebkura cita suga mēs izdzīvojam, pateicoties iepriekšējo paaudžu uzkrātajai pieredzei. Šī pieredze jānodod tālāk bērniem, lai viņi būtu pasargāti. Teorētiski bērni paši varētu no savas pieredzes iemācīties neiet pārāk tuvu pie klints malas, neēst nezināmas sarkanas ogas, nepeldēt krokodilu pilnā ūdenskrātuvē. Taču dabiskās izlases kontekstā priekšrocība būs bērna smadzenēm, kas tendētas šīs lietas iemācīties no pieaugušajiem, bez ierunām ticot, ko tie viņiem norāda. Kopumā tā ir noderīga iezīme, ja vien nenotiek kḷūme kā gadījumā, kad tādā veidā notiek inficēšanās ar reliğijas vīrusiem.

Interesants, bet augstākā mērā kontrintuitīvs tālāks secinājums mēmu teorijā - līdzīgi kā Dokinsa "savtīgie gēni” vai arī vīrusi, kas neatkarīgi no mums realizē savas programmas mūsos kā saimniekorganismos, tā arī mēmu teorijā patiesie "labuma guvēji" ir nevis cilvēki, bet gan paši reliǵiskie mēmi, kas izplatās caur saimnieksmadzenēm. Šo atziņu kodolīgi izsaka cits prominents KRZ pārstāvis - antropologs Skots Atrāns (Scott Atran): "Kultūras un relig̣ijas ir mēmu koalīcijas, kas tiecas maksimizēt savu pašu dzīvotspēju neatkarīgi no tā, ko tas dzīvotspējas izteiksmē izmaksā saimniekorganismiem - cilvēkiem." ${ }^{14}$

Nākamais KRZ celmlauzis, ko nevar apiet, ir Stjuarts Gatrijs (Stewart Guthrie) - prominents religijas kā antropomorfas projekcijas teorijas proponētājs mūsdienās. Gatrijs 1980. gadā formulē svarīgu KRZ postulātu, proti, ka cilvēka prāts tendēts saredzēt no vides saņemtu neskaidru informāciju antropomorfi (t. i., attiecināt cilvēciskas iezīmes uz

${ }_{13}$ Richard Dawkins, The God Delusion (New York: Houghton Mifflin, 2006), 174 et passim.

14 Scott Atran, In Gods We Trust: The Evolutionary Landscape of Religion (Oxford: Oxford University Press, 2002), 17. 
fenomeniem, kas nav cilvēciski un personiski). ${ }^{15}$ Gatrijs tipiski raksta:

Es apgalvoju, ka mēs antropomorfizējam, jo minējums, ka pasaule ir cilvēkveidīga, ir labs minējums. Tas ir minējums, jo pasaule ir neskaidra, nenoteikta un prasa interpretāciju. Tas ir labs minējums, jo visvērtīgākās interpretācijas parasti ir tās, kas atklāj kā klātesošu to, kas mums ir vissvarīgākais. Parasti tie ir citi cilvēki. ${ }^{16}$

Antropomorfisms universāli darbojas gan ikdienas izziņā, gan relig̣ijā. Šai antropomorfizēšanas tieksmei ir izšķ̌iroša nozīme, izskaidrojot cilvēkos izplatīto tendenci ticēt pārdabisku būtņu esamībai.

Teorija pati par sevi nav jauna. ${ }^{17}$ Jauns 20. gadsimtā bija tieši kognitīvais antropomorfisma izskaidrojums ar sava veida mentālu refleksu - secināšanas mehānismu, kas attīstījās mūsu senčos, palīdzot tiem izdzīvot nedrošā pasaulē. Kā jau minēts ievadā, šis mehānisms sākotnēji neattīstījās tieši religiskiem mērķiem. KRZ terminologijāā tas drīzāk ir universālās antropomorfizēšanas tendences "blakusprodukts". Vēl svarīgi atzīmēt, ka Gatrija postulāts arī paredz ticību pārdabiskām, bet tanī pašā laikā antropomorfām jeb cilvēkveidīgām, ar nodomiem jeb intencionalitāti apveltītām būtnēm jeb pārdabiskiem ag̛̣entiem kā reliǵijas raksturīgāko iezīmi. Šeit svarīgs arī saistīts pieņēmums par personisku ag̉entu zināšanu, proti gan dabiskas, gan pārdabiskas, gan reālas, gan iedomātas personas ne vienmēr ir tieši novērojamas kā ar nodomiem apveltīti ağenti, un tāpēc viņu klātbūtne ir jāizsecina no pieejamās informācijas. Taču šĩ informācija bieži vien ir nepietiekama, lai ag̉enta klātbūtni varētu droši zināt. Tātad ağenta darbība bieži vien netiek uztverta tieši, bet gan tiek neapzināti izsecināta no kādas iedarbības (piem., skaņas, kustības vai tml.). Galvenais

15 Stewart Guthrie, "A Cognitive Theory of Religion," Current Anthropology 21:2 (1980), 181-203.

16 Stewart Guthrie, Faces in the Clouds: A New Theory of Religion (Oxford: Oxford University Press, 1993), 3.

17 Filozofijas vēsturē rudimentārā formā šāda teorija bija pazīstama jau sengrieķu sofistiem, to proponējuši arī Deivids Hjūms, Benedikts Spinoza u. c. filozofi. 19. gadsimtā to vispilnīgāk izstrādājis vācu reliğijas filozofs Ludvigs Feierbahs darbā "Kristietības būtība". 
slēdziens religijias rašanās sakarā ir tāds, ka cilvēka prāts ir attīstījies tā, ka viegli izsecina personisku, ar nodomiem apveltītu aǵentu klātbūtni un darbību arī situācijās, kurās šādu agentu nav.

Lai arī Gatrija teorija pati par sevi nav pietiekama, lai pilnībā izskaidrotu religijiju kā ticību pārdabiskiem agentiem, tomēr tā vismaz izskaidro, kāpēc ticība pārdabiskiem ag̉entiem rodas tik viegli un ir tik izplatīta. Tādējādi Gatrija antropomorfisma postulāts jau savā laikā iezīmē un ilustrē KRZ svarīgo reliğijas kognitīvā “dabiskuma” pieņēmumu jeb t. s. religijias dabiskuma tēzi. ${ }^{18}$

Ar KRZ sākumiem asociē arī Tomasa Lousona (Lawson) un Roberta Makaulija (McCauley) 1990. gadā iznākušo grāmatu. ${ }^{19}$ Šie autori piemēro kognitīvo pieeju reliǵisko rituālu pētniecībā, definējot universālus formālus principus, kas ierobežo un nosaka rituālu izgudrošanu un dalību tajos. Tā kā religisiskie rituāli ir vērsti uz pārdabisku ağentu darbībām vai imitē šādas darbības, tos ierobežo universāla kognitīvo mehānismu sistēma, kas darbojas jebkādu darbību reprezentācijai. Visām darbībām ir kopīgi formāli elementi (piem., darbības "ağents" un "pacients"). Šos formālos kognitīvos elementus var izmantot relig̣isko rituālu tipolog̣ijas izveidei (piem., speciālie aǵentu rituāli un speciālie pacientu rituāli), kā arī dažādu tipu rituālu sastopamības noteikšanai dažādās religiskās tradīcijās.

Pati aǵentu konstatēšanas mehānisma koncepcija vēlāk tiek pilnveidota. Tiek formulēts KRZ izdaudzinātais kognitīvais modulis, saukts pārjūtīgais/hiperaktīvais aǵentu saredzēšanas mehānisms, kas ieviesies plašā apritē ar akronīmu HADD (hypersensitive / hyperactive agency detection device). Tā autors ir Džastins Barets (Justin Barrett). ${ }^{20}$

18 Relig̣ijas "dabiskuma” pieņēmumu ilustrē daudzi KRZ jomā publicētu grāmatu nosaukumi, kā "Relig̣isko ideju dabiskums" (Pascal Boyer, The Naturalness of Religious Ideas: A Cognitive Theory of Religion), "Kāpēc religija ir dabiska, bet zinātne nav" (Robert McCauley, Why Religion is Natural and Science is Not), "Religija kā dabisks fenomens" (Daniel Dennett, Breaking the Spell: Religion as a Natural Phenomenon) u. tml.

19 Thomas E. Lawson and Robert N. McCauley, Rethinking Religion: Connecting Cognition and Culture (Cambridge: Cambridge University Press, 1990).

20 Justin L. Barrett, Why Would Anyone Believe in God? (Walnut Creek, CA: AltaMira, 2004), 32ff. 
Nereti tiek stāstīts tamlīdzīgs stāsts. Mūsu aizvēsturiskais sencis - hominīds - izdzird, ka krūmos iečaukstas lapas. Vai tur ir lauva, vai arī tas ir tikai vējšs? Bēgt vai ne? Tāda ir dilemma. Iespējams kḷūīities divējādi. Var bēgt, bet izrādās, ka tas bija vējš. Tas ir "viltus pozitīvs". Zaudējums ir niecīgs - bēgšanai patērētā energijija un laiks. Bet var arī nodomāt, ka lapas čaukstina vējš, un nebēgt, un tad... nonākt lauvas nagos. Tas ir "viltus negatīvs", kas var izrādīties letāls. Tāpēc dabiskās atlases procesā uzvarēja piesardzīgais minējums (better safe than sorry) - pieņemt, ka ağents ir klātesošs. Evolūcijas kontekstā HADD ir sava loma izdzīvošanā, un tas palīdz hominīdu sugai àtri identificēt vajadzīgos reālos aǵentus vai arī izvairīties no nevēlamajiem reālajiem aǵentiem. Bet "viltus pozitīvu” (kognitīvo mehānismu kḷūdainas funkcionēšanas dēḷ saskatot agentu darbību tur, kur ağentu nav) blakne ir tāda, ka daudzi cilvēki rezultātā tic pārdabisku ag̉entu (dievu, garu, spoku, raganu, troḷı u u. c.) eksistencei.

Izplatītākie pārdabisko aǵgentu veidi senajā pasaulē saistās ar tādām dabisko aǵentu kategorijām, ko senajiem cilvēkiem bija vissvarīgāk saredzēt: plēsoņa vs. medījums, aizsargātājs vai partneris vs. sāncensis. Hiperjūtīga tādu aǵentu (dzīvnieku vai citu cilvēku) saredzēšana, kas gribētu tevi nogalināt vai ko tev vajadzētu nogalināt (pārtikai), dod izdzìvošanas priekšrocības. Tāpat izdzīvošanai svarīgi ir aizsargātāji un partneri. Piemēram, bērni automātiski meklē aizsargātāju tuvumu, viņos aktivizējas uzvedības mehānismi, kas identificē aprūpētāju un veido ar viņu pieķeršanās saiti. Tas ir svarīgi izdzīvošanai līdz patstāvīgam vecumam. Liela nozīme izdzīvošanā ir arī partneru (prokreācijas) un palīgu identificēšanai. Tiek secināts, ka pastāvīgā modrība esošo un potenciālo ag̉entu identificēšanā tālāk veicināja arī tādu neredzamu ag̉entu kā dievi/Dievs darbības saskatīšanu aiz visiem dabas fenomeniem.

HADD darbojas reizē ar citiem KRZ identificētiem kognitīviem mehānismiem, kas cilvēka prātā galu galā rada noslieci uz religiozitāti. Viens no tādiem ir t. s. prāta teorijas mehānisms (ToMM - theory of mind mechanism/module) ${ }^{21}$ Kaut arī

${ }_{21}$ "Prāta teorija" (Theory of Mind, ToM) ir plaši lietota koncepcija psiholog̣ijā. Pirmo reizi šādā nozīmē apzīmējumu ievieš amerikāṇu psihologs Deivids Premaks (David Premack) 1978. gadā rakstā par eksperimentiem ar šimpanzi. David Premack and Guy Woodruff, "Does the 
HADD identificētais aǵents neeksistē realitātē, ToMM tik un tā darbojas, piedēvējot iedomātajam agentam tālākas iezīmes, īpaši tādas, kas saistās ar nolūkiem ("hiperaktīva nodomu saredzēšana”). Tiklīdz senais cilvēks iedomājas, ka ir samanījis ag̉entu, tā tūlìt automātiski piedēvē tam savējiem līdzīgus mentālos un emocionālos stāvokḷus, it kā "nolasa" citu prātu (mind reading), pieņem, ka iedomātais "cits prāts", kas piemīt neredzamajam aǵentam, darbojas teleologiski jeb mērkstiecīgi, un cilvēks viegli piedēvē šim ağentam tādas iezīmes kā interese būt saskarsmē ar cilvēku, spēja dusmoties uz cilvēku, izrādīt labvēlību u. tml. Psihologiijā šo tendenci pazīst kā mentalizāciju jeb "domāšanu par domāšanu" - spēju saprast mentālus jeb apziņas stāvokḷus, kas nosaka uzvedības. Tā ir iztēles darbība, kas liauj uztvert un interpretēt uzvedību kā izrietošu no apzinātiem mentāliem stāvokḷiem, kā vajadzības, vēlmes, sajūtas, pārliecības, mērksi, iemesli u. c. Šiem mehānismiem ir svarīga nozīme komunikācijā ar līdzcilvēkiem, taču tiem ir "blakne" - tie mudina saredzēt mentālus un emocionālus stāvokḷus arī tur, kur nav aǵentu un līdz ar to arī nav šādu stāvokḷu, t. i., piedēvēt šos stāvokḷus neitrāliem, bezpersoniskiem fenomeniem.

Līdzīgi darbojas arī "ikdienas duālisma" (common-sense dualism) kognitīvais mehānisms. ${ }^{22}$ Kognitīvā zinātne cilvēka prātā atklāj dažādus kognitīvos modulus, kas darbojas atšķirīgi fizikālu k̦ermeņu un mentālu fenomenu gadījumos. Tiek secināts, ka tāpēc cilvēkam arī rodas tendence saskatīt ķ kermeni un dvēseli kā atšksirīgas entitātes. Šis apstāklis arī veicina tendenci saredzēt aǵentu darbību tur, kur nav fizikālu pierādījumu par to klātbūtni, kā arī piedēvēt mentālus stāvokḷus iedomātām būtnēm bez fiziska k̦ermeņa. Galu galā šo hiperaktīvo kognitīvo "noklusējuma iestatījumu" rezultātā senajos cilvēkos rodas ticība dieviem un Dievam.

Kognitīvā reliğijas zinātne pieņem, ka kognitīvie uzdevumi, kas ir būtiski reproduktīvai ilgtspējai, tiks iedzīvināti ar īpašiem kognitīviem mehānismiem, lai nodrošinātu to īstenošanas vienkāršību, ātrumu un drošumu. Jo sarežǵìtāks uzdevums, jo

Chimpanzee Have a Theory of Mind?," in Behavioral and Brain Sciences 1:4 (1978), 515-526.

22 Paul Bloom, "Religion is Natural," in Developmental Science 10:1 (2007), 147-151. 
nepietiekamāka ir vidē pieejamā informācija, un tāpēc veiksmīga īstenošana ir atkarīga no pašā kognitīvajā sistēmā esošās informācijas (shēmas, noteikumi, scenāriji utt.). No š̄̄s "iebūvētās” informācijas maz kam ir tiešs sakars ar reliǵiju. Tomēr šī informācija visa pārējā starpā ierobežo un nosaka arī reliǵiskās idejas, ticības un uzvedību. Mēs vispār nespējam domāt un rīkoties citādi nekā saskaņā ar shēmām, ko mums nodrošina mūsu sugai specifiskie kognitīvie mehānismi.

Šì ir cita ievērojama antropologa un KRZ celmlauža Paskāla Bojēra (Pascal Boyer) - galvenā atziņa. ${ }^{23}$ Bojērs ievēro, ka ticību pārdabiskām būtnēm pavada saistītu konkrētu tēmu vai ideju ievērojama atkārtošanās. Sekojot Sperbēra ideju epidemiologijas tēzei, Bojērs cenšas izskaidrot, kāpēc viena veida religisiskie priekšstati atkārtojas dažādās kultūrās, bet citi - ne. Saskaņā ar Bojēru reliğiskie priekšstati, kas atkārtojas, pieder pie noteiktiem kategoriju kopumiem jeb "repertuāriem". Repertuāri atbilst parastās, ikdienišksā̄s domāšanas specifiskiem domēniem, kuros caur ToMM darbojas cilvēka prātā "iebūvētas", neapzinātas specifiskas secināšanas mehānismu sistēmas jeb moduḷi, ko kognitīvās zinātnes literatūrā mēdz apzīmēt arī kā "tautas fiziku" (folk physics, cilvēku ikdienišķa izpratne par dabas parādībām), "tautas mehāniku” (folk mechanics, ikdienišksa izpratne par to, kā objekti kustas un mijiedarbojas), "tautas psiholog̣iju” (folk psychology, cilvēku ikdienišksa spēja izskaidrot un prognozēt citu cilvēku uzvedību un mentālo stāvokli), "tautas biologijiju” (folk biology, uztvertu organismu taksonomiska iekl̦aušana vienā vienīgā sugas [savējās] klasē).

Bojēra ievērojamākais pienesums šinī kontekstā un arī ideju epidemiologijas teorijas tālākā izstrādē ir pieņēmums, ka religiskās idejas drīzāk tiks saglabātas un nodotas tālāk, tātad atkārtosies tad, kad tās tikai nedaudz koriğē "iebūvēto" kognitīvo sistēmu sagaidāmo, mērenā proporcijā pārkāpjot domēniem specifiskos sagaidāmos priekšstatus (ne pārāk daudz, ne pārāk maz). Piemēram, spoks ir persona, kurai, atšksirībā no parastām personām, nav fiziska k̦ermeņa, bet kura citādi

23 Pascal Boyer, The Naturalness of Religious Ideas: A Cognitive Theory of Religion (Berkeley, CA: University of California Press, 1994); Pascal Boyer, Religion Explained: The Evolutionary Origins of Religious Thought (New York: Basic Books, 2001). 
iekḷaujas normālos personām piemītošu īpašību rāmjos (attiecībā uz intencionalitāti, zināšanu, atmiņu, uztveri u. c.). Spoka ideja reizē ar citu veidu pārdabisko ağentu idejām pieder pie tādām idejām, ko KRZ apzīmē kā minimāli kontrintuitīvas (minimally counterintuitive, MCI) idejas - idejas, kas minimāli pārsniedz normāli sagaidāmo. MCI idejas tik viegli tiek nodotas tālāk, jo tās piesaista, - ir interesantas, raisa bagātīgu iztēli un viegli iegulst atmin̄ā, t. i., tām piemīt mnemoniska priekšrocība pār idejām, kas iekḷaujas sagaidāmajos rāmjos.

\section{Prosociālie mehānismi}

KRZ pārstāvji bieži pieņem, ka reliğiskajām kultūrām raksturīgā ticība pārdabiskajiem spēkiem ir maldīga (piem., pamatojas uz ağentu mērķtiecīgu darbību kḷūdainu piedēvēšanu neitrāliem dabas fenomeniem). Bet šī dziļi iesakņojusies tendence uz kognitīvo kḷūdu rada mīklu evolucionārās psiholog̣ijas kontekstā - t. s. cenas mīklu.

Religijija cilvēkam dārgi maksā - prasa nodoties visu dzìvi, iztērēt lielu daḷu laika darbībām, kurām nav redzama rezultāta, utt. Iznāk, ka reliǵijas pamatā ir mūsu sugai vispārīgi piemītoša l̦oti dārga slieksme uz maldīgām ticībām. Kā tas nākas, ka šì domājami maldīgā slieksme uz reliǵiozitāti ir izkḷuvusi cauri dabiskās atlases filtriem mūsu senču vidē, kur tendence sistemātiski kḷūīities varētu būt bijusi nelabvēlīga izdzìvošanai? N̦emot vērā milzīgo iespaidu kultūrā, šo slieksmi arī nevar uzskatīt par nenozīmīgu blakusefektu citādā ziņā drošai un uzticamai kognitīvajai arhitektūrai. Kā atzīst kognitīvās psiholog̣ijas pētnieks Stīvens Pinkers (Steven Pinker), "mūsu universālā nosliece uz religisku ticību ir īsta zinātnes mīkla". ${ }^{24}$

Viens no KRZ cenas mīklas risinājumiem ierosina, ka reliǵisko ticību dārgo maksu kompensē dažādi prosociālie labumi, veicinot grupu saliedēšanu, paklausību sabiedriskām normām, lojalitāti grupai un tās vērtībām, savstarpīgumu, sadarbošanos u. c. Reliğisko ticību un prakšu "dārdzība" padara to efektīvu un derīgu sociālā jomā. Pēc tam kad prāta

24 Steven Pinker, “The Evolutionary Psychology of Religion," in Where God and Science Meet: How Brain and Evolutionary Studies Alter Our Understanding of Religion. Evolution, Genes, and the Religious Brain, Vol. 1, ed. Patrick McNamara (Westport, CT; London: Praeger, 2006), 8. 
kognitīvie mehānismi radījuši pārdabisko aǵentu priekšstatus, tie tālāk tiek kopti un kultivēti kultūrā, pateicoties prosociālās adaptācijas mehānismiem. Tie ir mehānismi, kas veido un uztur kopienas un kas hiperaktīvi darbojas, aizsargājot savas grupas saliedētību. ${ }^{25}$

Prosociālo pieeju pārstāv, piemēram, t. s. dārgās signalizēšanas (costly signaling) teorija, ko izstrādājuši Ričards Sosiss (Richard Sosis), Džozefs Balbulia (Joseph Bulbulia) u. c. antropologi. ${ }^{26}$ Šìs pieejas sākuma punkts ir kooperatīvās uzvedības sistēmu vājajā vietā, ka tās var savtīgi izmantot krāpnieki, veltēdāji un atkritēji. Tāpēc vajadzīgs veids, kā atšksirt šos krāpniekus no tiem, kas ir godīgi un lojāli kooperācijas sistēmai. Viena iespēja ir, ka godīgie "signalizē" citiem savu lojalitāti. Protams, tas nedarbosies, ja šos signālus būs viegli viltot. Signāliem jābūt "noturīgiem pret viltošanu" (hard-to-fake). Tāpēc tie jāpadara maksimāli "dārgi”. Citiem vārdiem, ja godīguma signālu cena pārspēj labumu no krāpšanās, tad var būt zināma drošība par signalizētāja labajiem nodomiem. Tādējādi reliǵijas dārgās signalizēšanas funkcija, veicinot grupas solidaritāti, padara reliǵiozitāti par adaptīvu iezīmi grupas izdzīvošanas kontekstā. Šis labums ar uzviju kompensē kognitīvās kḷūdas nodarīto kaitējumu individuālā līmenī.

Pārdabiskie aǵenti, kā gari, senči, dievības u. c., pilda arī aizsardzības funkciju. Cilvēku kopienām palielinoties, kḷuva aizvien grūtāk kontrolēt, vai ikviens ievēro kopienas normas. Taču, kad kopienas locekḷi tic bezķermeniskiem, nodomu vadītiem spēkiem, kas ir ieinteresēti viņu uzvedībā un kam ir vara un vēlme viņus apbalvot vai sodīt, tad šādi cilvēki, visticamāk, ievēros noteikumus pat tad, kad uzraugošie iemiesotie cilvēciskie ağenti neredz. Tādējādi arī šis bija êrts veids, kā tikt galā ar savtīgajiem krāpniekiem, kas apdraud kopienas labklājību. Atriebīgi pārdabiski aǵenti varētu pieķert sliktās uzvedības gadījumus, ko dabiskie agenti varētu palaist garām nepamanītus, un varētu sodīt ne tikai pārkāpējus, bet arī viņu pēcnācējus vai pat visu kopienu. Neredzamu "vērotāju" eksistences

${ }_{25}$ LeRon F. Shults, Theology after the Birth of God: Atheist Conceptions in Cognition and Culture (New York: Palgrave Macmillan, 2014).

26 Joseph Bulbulia and Richard Sosis, "Signalling Theory and the Evolution of Religious Cooperation,” Religion 41:3 (2011), 363-388. 
pieņēmums palielina motivāciju paklausīt kopienā pieņemtajiem noteikumiem un palikt uzticīgiem kopienai. ${ }^{27}$

Ar iepriekšējo saistīta ir arī pārdabisko ağentu morālā funkcija. Berings un Džonsons formulē šo KRZ atziņu šādi:

Ikviena moralizējošu pārdabisku aǵgentu instance ir tikai vēl viena izteiksme mūsu priekšteča adaptīvajam psiholoǵiskajam mehānismam, kas acīmredzami attīstījās, lai varētu tikt galā ar pēkšnno apzināšanos, ka citi prāti kopienā cieši pārrauga tavas darbības morālajā jomā. ${ }^{28}$

Kognitīvie moduḷi, kas atbildīgi par cilvēka iekšējo morālo izjūtu, sadarbībā ar ToMM viegli pārnes šo morālo izjūtu uz pārdabiskajiem ağentiem. Vienmēr sanāk tā, ka pārdabisko aǵentu iedomātās vēlmes sakrīt ar kopienas intuitīvajiem morāles pieñēmumiem. Protams, pārdabisko ağentu vēlmes zina "eksperti” (piem., priesteri), kuru rekomendācijām ir jāseko. Arī tas ir veids, kā panākt, lai kopienas locekḷi uzvestos saskaņā ar pieņemtajām normām.

\section{No KRZ teorijām atvasinātu antiteistisku argumentu piemēri}

KRZ iesaistītie zinātnieki dažādi attiecas pret savu pētniecības priekšmetu - reliğiju. Ir tādi KRZ pārstāvji, kas teicami cenšas saglabāt zinātnei piedienīgi neitrālu, objektīvu, bezaizspriedumainu attieksmi un tādējādi nepārkāpt zinātnes nospraustās robežas. ${ }^{29}$ Galu galā, kā redzēsim tālāk, tādi jautājumi kā religíisko ticību pamatotība vai religijas patiesums nav un nevar būt empīrisks zinātnes jautājums, bet drīzāk ir piekritīgs relig̣ijas filozofijai un teolog̣ijai. Dažiem ir arī labvēlīga attieksme pret reliǵiju, īpaši tiem, kas paši savā personīgajā dzīvē ir reliğiozi cilvēki vai teisti. Šie zinātnieki atrod veidus,

${ }_{27}$ Šo diskusiju skat.: LeRon F. Shults, Theology after the Birth of God, 26-30.

28 Jesse M. Bering and Dominick D. Johnson, “'O Lord... You Perceive My Thoughts From Afar': Recursiveness and the Evolution of Supernatural Agency," Journal of Cognition and Culture 5 (2005), 136.

29 Šeit neattīstīšu argumentus, vai "objektīva" attieksme principā ir vai arī nav iespējama. Runa ir tikai par zinātniskas pieejas ideālu. Arī pašā zinātnisko teoriju konstruēšanas praksē ir grūti palikt uzticīgiem tikai faktiem, jo teorija paredz interpretāciju. 
kā integrēt KRZ secinājumus savās ticības sistēmās bez ievērojamiem teologíiskiem "zaudējumiem". Galvenokārt tomēr KRZ pārstāvji ir naturālisti un ar savām religijas teorijām tieši vai netieši paredz reliğisko ticību domājamo maldu "atmaskošanu". Kad religijia ir šādi zinātniski izskaidrota ar cilvēka dabiskā prāta izspēlētiem trikiem, tad pamatojumiem un motivācijai nodoties religisiskām ticībām vajadzētu pazust. Kognitīvajā religijas zinātnē pat tiek saredzēts ilgi gaidìtais pamats zinātnes pēdīgajai uzvarai pār Dievu. Kā KRZ kontekstā braši apgalvo psihologijijas profesors Džesijs Berings (Jesse Bering): "Mūsu sugas vēsturē mēs esam pirmā paaudze, kas tieši sadursies ar neapgāžamu zinātnisko pamatojumu argumentam, kas padara personīgu Dievu gan nevajadzīgu, gan ārkārtīgi maz ticamu." ${ }^{30}$

Vai ir pamats neapšaubāmi pieņemt šādus apgalvojumus? Tas tiks apskatīts tālāk, kamēr šeit tiks sniegti daži raksturīgi uz KRZ balstīti antiteistisku argumentu piemēri. Izklāsta īsuma labad uzskaitījums nebūs izsmel̦ošs un būs samērā formalizēts. ${ }^{31}$ Argumentus var iedalīt lielākās grupās:

A. Argumenti, kas paredz to, ka religijas dabiskie izskaidrojumi padara teistiskos izskaidrojumus liekus, nevajadzīgus. Šeit var piesaukt arī parsimonijas jeb “Okama naža” principu - "nogriezt" liekās, nepamatojamās hipotēzes. KRZ koncepcijas drīzāk kalpo kā evidence par labu relig̣isko ticību objektu neeksistencei. Śo vispārīgo nostādni dažādās formās apriori pieņem ateistiski orientēti KRZ pārstāvji.

B. Argumenti, kas pamatoti ar pienēmumu, ka nevar uzticēties kognitīvajiem mehānismiem, kas formē mūsu relig̣iskās ticības. Teistu ticība ir iracionāla, jo kognitīvie mehānismi, kas mūs noved pie ticēšanas, ir neuzticami. Šajā grupā

${ }^{30}$ Jesse Bering, The Belief Instinct: The Psychology of Souls, Destiny, and the Meaning of Life (New York, London: W. W. Norton \& Company, 2011), 202. Citāta tulkojums aptuvens un interpretatīvs, šeit avotteksts: "We are the first generation, in the history of our species, to be confronted directly by the full scientific weight of an argument that renders a personal God both unnecessary and highly unlikely."

31 Šim uzskaitījumam pamatā (kaut arī nesekojot burtiski) izmantoti divi avoti: Justin L. Barrett, "Is the Spell Really Broken? Bio-psychological Explanations of Religion and Theistic Belief," in Theology and Science 5:1 (2007), 57-72; David Leech and Aku Visala, "The Cognitive Science of Religion: A Modified Theist Response," in Religious Studies 47:3 (2011), 301-316. 
identificējama rinda konkrētu argumentu (uzskaitījums nav izsmel̦ošs):

a) arguments, kas balstīts uz koncepciju par reliǵiju kā evolūcijas blakusproduktu. Kognitīvie mehānismi, kas formē religigiskās ticības, neizveidojās evolūcijas procesā, lai radītu šīs ticības, bet tapa kā blakusprodukts, evolūcijas procesā attīstoties citām izdzīvošanai nepieciešamām iezīmēm. Tāpēc šie mehānismi kā reliǵisko ticību avoti nevar būt droši. Reliǵiskās ticības ir kognitīvas ilūzijas;

b) arguments, kas atvasināts no cēlonssakarības trūkuma. Naturālistisku religijas izskaidrojumu rezultātā zūd cēlonssakars starp relig̣iskajām ticībām un to objektiem. Šîs ticības varētu būt patiesas, ja būtu demonstrējams sakars starp tām un to objektu. Bet tās ir tikai kognitīvo mehānismu radītas. Tāpēc tās nevar būt patiesas;

c) arguments, kas izriet no reliǵisko ticību dabiskuma. Mēs tagad zinām, kāpēc cilvēkiem ir reliǵiskās ticības. Tās neizraisa kaut kāds to objekts (piem., Dievs). Tās drīzāk dabiskā veidā generē kognitīvie mehānismi. Tāpēc ticēt tām ir iracionāli;

d) arguments, kas izriet no "viltus pozitiviem". Kognitīvie mehānismi producē daudzas maldīgas ticības pārliecības, tāpēc tiem nevar uzticēties. Nav saprātīgi uzskatīt, ka ticības, ko tie rada, ir patiesas;

e) arguments, kas izriet no religísko ticību dažādības fakta. Kognitīvo mehānismu producēto religisisko ticību dažādība, ieskaitot savstarpēji pretrunīgas ticības, liek secināt, ka šiem mehānismiem nevar uzticēties;

f) arguments, kas izriet no (religisisko ticību / kognitīvo mehānismu / prosociālās uzvedības) noderīguma. Dabiskā atlase uzturējusi religiskās ticības, pateicoties to noderīguma funkcijai (piem., sociālā plānā - sabiedrības saliedēšanai u. c.). N̦emot vērā, ka tā noticis to noderīguma nevis patiesuma dēl, uz šīm ticībām nevar paḷauties patiesuma vērtības ziñā;

g) arguments, kas balstīts uz koncepciju par ticības tālāk nodošanu ("epidemiologiiju”). Cilvēki lētticīgi pārņem religisiskās ticības (piem., no vecākiem un citām autoritā- 
tēm). Dabiskās atlases ceḷā cilvēkam ir tāds kognitīvais aparāts, kas viņu padara par reliǵisko ticību lētticīgu pārņēmēju. Tā kā tagad mēs zinām, kāpēc cilvēki tik viegli notic Dievam, turpināt ticēt nav saprātīgi un nav jēgas;

h) arguments, kas izriet no prāta tendences kḷūdīties (error-prone mind). KRZ demonstrē, ka mūsu prāta kognitīvie mehānismi mudina mūs pieņemt reliǵisko ticību. N̦emot vērā, ka šie mehānismi tendēti uz kḷūdīšanos, uz tiem nevar paḷauties patiesības ziñā. Tāpēc arī nevaram paḷauties uz stimuliem pieņemt religisiskās ticības, un KRZ tādējādi vājina relig̣iskās ticības.

\section{Teismam draudzīgu atbildes argumentu piemēri}

Kā jau minēju ievadā, teologi un relig̣ijas filozofi ir atbildējuši uz KRZ izaicinājumiem daudz, gari un plaši. Literatūras klāsts ir liels. Šeit būs iespējams iezīmēt tikai dažas atbildes. Rodas iespaids, ka lielākoties šīs atbildes reakcijas uz KRZ pamatotu religijias "atmaskošanu” grozās ap t. s. genēzes log̣isko kḷūdu (genetic fallacy). Religijas "atmaskošanas" gadījumā ši kḷūda izpaužas tā, ka no relig̣ijas genēzes jeb rašanās un tapšanas izskaidrojumiem tiek izdarīts secinājums par religíijas maldīgumu. Kḷūda ir tāda, ka reliǵisko ticību genēze dabiskā veidā ar kognitīvo mehānismu starpniecību vēl log̣iski nenozīmē to maldīgumu. Turklāt reliǵisko ticību patiesums nav nedz loǵiski neiespējams, nedz nepieciešami maldīgs pat tad, ja to genēzes izskaidrojumi izrādītos patiesi.

Atbildot uz KRZ piedāvātajiem relig̣iju "atmaskojošajiem" argumentiem, pirmkārt jau var norādīt, ka kognitīvie mehānismi rada visas mūsu pārliecības, - gan relig̣iskas, gan tādas, kurām nav sakara ar reliǵiju. Uz to arī skaidri norāda pats religijijas kā "blakusprodukta" statuss KRZ. Ko nu? Tas tik tiešām ir dīvains pieņēmums - ja kādai pārliecībai ir dabiski cēloṇi, tad tā ir nepamatota. Bet iznāk, ka nepamatotas ir ne tikai teistu, bet ikviena cilvēka ticības pārliecības. Tad vairs vispār nevar būt runas ne par kādu pamatotu zināšanu nevienā jomā - fizikā, matemātikā, ekonomikā utt. Vēl jo vairāk, reliǵijas "atmaskotāju" argumenti izrādās pašiznīcinoši, gribot negribot pavēršoties pret pašiem "atmaskotājiem" - piemēram, 
pret viņu pašu ateistiskajām ticības pārliecībām. Kā ievēro Džastins Barets un Īans Čērčs (Ian Church), ateisms kopā ar reliğijas izskaidrojumiem KRZ dod iemeslu apšaubìt tos pašus universālos ticības pārliecības veidojošos kognitīvos mehānismus, kas veido arī ticības pārliecības par ateisma un KRZ patiesumu. $^{32}$

Tāda pati, kā to nosauc Barets, "pašnāvnieciska tendence" seko argumentam, ar ko KRZ ateismu pieņēmušie pārstāvji cenšas diskreditēt reliǵiskās ticības, atsaucoties uz mūsu kognitīvo mehānismu vispārīgajiem epistemolog̣iskajiem ierobežojumiem, - argumentam, kas izriet no prāta tendences kḷūdìties. ${ }^{33}$ Kognitīvās zinātnes dod pierādījumus tam, ka mūsu prāti sistemātiski kḷūdās, "iemainot realitātes patiesu atspoguḷošanu pret izdzīvošanu un reprodukciju”. ${ }^{34}$ Protams, kognitīvie mehānismi nedod skaidras zināšanas, vai religisisko ticību objekti pastāv (vai Dievs eksistē), bet tas pats attiecas arī uz mūsu pārliecību par citu cilvēku prāta eksistenci, mūsu atmiņu ticamību, fizikas likumu pastāvību, evolūcijas patiesumu, KZR atklājumu pareizumu. ${ }^{35}$ Ir acīmredzams, ka mūsu prāts ir tendēts kḷūdīties. Tomēr, lai paglābtos no absolūta skepticisma, ir vismaz jāatzīst, ka tas nekḷūdās tādā pakāpē, ka tam vispār nevarētu uzticēties itin nevienā aspektā.

Šajā sakarā var arī dibināti uzdot jautājumu: ja jau visām ticības pārliecībām ir dabiski izskaidrojami cēloņi un tās nonāk pamatojuma problēmās tieši tādēl, ka tām ir šie dabiskie, kognitīvie cēloņi (kā tas izriet no KRZ), tad kāpēc šeit izcelt tieši un tikai reliğiskās pārliecības? Džeimss Džonss (James Jones) trāpīgi apraksta situāciju:

Šis ir mulsinošs gājiens. Kognitīvā zinātne parāda, ka relig̣ija balstās uz cilvēka kognitīvajiem mehānismiem. Uz kā gan cita tā varētu balstīties? Bet tad gandrīz nekavējoties cilvēka kognitīvās spējas relig̣ijas sfērā tiek pārdefinētas vairs ne tikai kā dabiskas, bet arī kḷūdainas, vai

${ }^{32}$ Justin L. Barrett and Ian M. Church, "Should CSR Give Atheists Epistemic Assurance? On Beer-Goggles, BFFs, and Skepticism Regarding Religious Beliefs," in The Monist 96:3 (2013), 317.

33 Justin L. Barrett, "Is the Spell Really Broken? Bio-psychological Explanations of Religion and Theistic Belief," 67.

34 Ibid., 70 .

35 Ibid. 
vēl sliktāk... Ne mirkli nevilcinoties, atmaskotāji pāriet no religijias kā dabiskas uz relig̣iju kā vienmēr kḷūdainu un bieži patolog̣isku. ${ }^{36}$

Savādi ir arī tas, ka dabiski radušos reliǵisko pārliecību diskreditācija netieši paredz pretējo - ka reliǵiskās ticības varētu būt pamatotas, ja tās nebūtu radušās dabiski, bet tām būtu reāls pārdabisks avots. Loğiski šeit nav, ko iebilst. Tāpat ir arī daudzi ticīgie, kas domā, ka religisiskās pārliecības ir pārdabiski pamatotas, piemēram, atklāsmē. Taču no pašām teisma pozīcijām nav absolūti nepieciešami pieņemt šādu viennozīmīgu nostāju. Lielākoties teisti saredz Dieva darbību caur dabiskiem cēloņiem, kā arī saskata cilvēka prātu kā dabiski spējīgu zināt Dievu. ${ }^{37}$ Tādējādi vairumam teistu nebūtu problēmu saskatīt arī dabiski radušās religiskās pārliecības kā pamatotas.

Jāatzīst arī atšksirība starp "atmaskotājiem” un teistiem. Pirmie domā, ka kognitīvie faktori ir vienīgais religijas avots, bet pēdējie parasti domā, ka Dievs tomēr ir religijas primārais avots, kamēr kognitīvie faktori ir sekundārais avots. "Atmaskotāji” to nekad nepieņems, uzskatot, ka kognitīvie mehānismi veido reliǵiskās ticības neatkarīgi no jebkādiem pārdabiskiem aǵentiem. Religiskās ticības pārliecības ir dabiskā evolūcijas procesa neparedzēti "blakusprodukti”, kas veicina piemērotību izdzīvošanai dabiskās atlases apstākḷıs. Katrā gadījumā KRZ izskaidrojumos nav vietas nekādai pārdabiskai cēlonībai. Un tieši tā tam arī zinātnē ir jābūt. Bet kas šajā situācijā notiek? Arguments kḷūst lieks. KRZ teorijas kauzāli neatsaucas uz reāliem pārdabiskiem aǵentiem, bet pats fakts, ka tās neatsaucas uz šādiem ağentiem, vienkārši nozīmē to, kas ir acīmredzams un pats par sevi saprotams - ka šīs teorijas ir naturālistiskas, kognitīvas, un viss.

Teisti šajā situācijā var turpināt ticēt ar savām ticības pārliecībām. Vien̄̄gais veids, kā to aizkavēt, būtu reizi par visām reizēm pierādīt, ka naturālisms ir absolūti patiess, ka nav Dieva un nekādu citu pārdabisku ağentu, kam reliğiozi cilvēki tic, un ka attiecīgās ticības ir nepieciešami maldīgas. Bet kā lai "atmaskotāji” to izdara, ja šādi pierādījumi ir principā

36 James W. Jones, Can Science Explain Religion? The Cognitive Science Debate (Oxford: Oxford University Press, 2016), 82.

${ }_{37}$ Šos apsvērumus skat.: James W. Jones, op. cit., 77. 
ārpus KRZ ekspertu jomas? KZR joma tomēr ir kognitīvie mehānismi, nevis ontologija - kā jautājumi, vai Dievs vai citi pārdabiski aǵenti patiesībā eksistē vai arī tikai daba ir viss, kas ir. Šādiem pierādījumiem būtu vajadzīga neatkarīga evidence. Tādējādi disputs starp religijas "atmaskotājiem" un teistiem pēc būtības ir nevienprātība attiecībā uz naturālismu. ${ }^{38}$ Reliǵisko ticību pamatojums pieder citai, no KRZ atšksirīgai jomai. Un šajā situācijā, kad KRZ pārstāvji izvirza apgalvojumus par religigisko ticības pārliecību maldīgumu, viņiem var dibināti jautāt, kā to dara, piemēram, Alvins Plantinga, - vai viņi izdara šos secinājumus savas zinātnes jomas ekspertu kapacitātē? Vai šie secinājumi pieder viņu zinātnei? ${ }^{39}$

Svarīgi arī pieminēt - teisti tipiski norāda, ka KZR atklātie kognitīvie mehānismi nav vienīgie faktori, kas rada religiskās ticības. Nav izslēgts, ka darbojas arī uzticamāki faktori. Kā atzīmē Džonss, "pat ja tiktu parādīts, ka iesaistītie kognitīvie mehānismi ir absolūti neuzticami, tas vēl nenozīmētu, ka nevar būt iesaistīti arī citi, uzticamāki faktori”". ${ }^{40} \mathrm{Ka}$ šajā sakarā norāda Deivids Līčs un Aku Visala, KZR piedāvā tikai universāli izplatītu relig̣isku ticību rašanās mehānismus (ultimate mechanisms), bet nepiedāvā tādus mehānismus, kas darbojas konkrētās ticības pārliecībās ar konkrētu saturu (proximate mechanisms), kur mijiedarbojas dažādi mehānismi un faktori. ${ }^{41}$

Tālāk var jautāt, vai nevarētu būt arī tādi kognitīvie faktori, kuriem var uzticēties, pat relig̣ijā? N̦emot vērā, ka kognitīvie mehānismi darbojas zemapzin̄ā, tad pirmais uzticamāka faktora kandidāts var būt nekas cits kā racionālais prāts. N̦emsim par piemēru HADD. Ja tas aǵentu noteikšanā darbotos viens, mēs nekad nevarētu skaidri atšksirt kḷūdu. Kā ievēro Barets, par laimi, ir arī citi kognitīvie faktori, kas var palīdzēt izlabot HADD kḷūdu - piemēram, spēja reflektīivi izvērtēt evidenci. ${ }^{42}$

38 Skat. James W. Jones, op. cit., 79.

39 Skat. Alvin Plantinga, "Games Scientists Play," in The Believing Primate: Scientific, Philosophical, and Theological Reflections on the Origin of Religion, eds. Jeffrey Schloss and Michael Murray (Oxford: Oxford University Press, 2009), 154.

40 James W. Jones, op. cit., 131.

${ }^{41}$ David Leech and Aku Visala, "The Cognitive Science of Religion: A Modified Theist Response," 313.

${ }^{42}$ Justin L. Barrett, "Is the Spell Really Broken? Bio-psychological Explanations of Religion and Theistic Belief," 68. 
Tas var būt īpaši svarīgi pārdabisko aǵentu gadījumā, kur nav objektīva testa, ar ko izvērtēt viltus pozitīvus. Analītiskajai spriešanai var būt ne mazāka nozīme religisisko ticību formēšanā, un tā var būt uzticamāks instruments religisko ticību izvērtēšanā - kas jau ir religijas filozofu un teologu, nevis KRZ ekspertu kompetence.

Vēl diezgan izplatīta teistu stratēgija ir pieņemt, ka kognitīvie mehānismi rada nevis maldīgas, bet gan patiesas religiskās ticības. Un to nodrošina tieši dievišksu spēku darbība. Lūk, šādai pārliecībai raksturīgs citāts:

Varētu būt pilnīgi pareizi teikt, ka Dievs ir radījis cilvēkus vai iekustinājis dabiskos notikumus, kas padarīja par neizbēgamu to, ka evolūcijas procesi noris cilvēkā, ar ticības formējošiem mehānismiem, kas padara reliǵisko ticību iespējamu vai neizbēgamu. Tad var būt vienlīdz pareizi teikt, ka mums ir slieksme veidot reliǵgiskās ticības, jo tās ir patiesas. ${ }^{43}$

Šis citāts arī ilustrē pieeju, kas pielāgo KRZ teismam. Tā ir savā ziņā līdzīga stratēgijai, kas pielāgo evolūciju teismam. ${ }^{44}$ KRZ reliğijas skaidrojumi tiek pilnībā pieņemti, taču izmantoti kā evidence nevis pret religiju, bet gan tās labā. Dieva darbība tiek saredzēta reliǵiskās ticības veidojošajos procesos. Dievs tos izmanto saskarsmei ar cilvēku. Cilvēka smadzenes ir tādējādi "iestatītas” kontaktam ar dieviškso realitāti.

Šajā kontekstā interesanti atzīmēt, ka viens no iepriekš minētajiem vadošajiem KRZ pārstāvjiem - Džastins Barets, arī HADD koncepcijas autors - savu izcilo zinātnieka darbību kognitīvajā psihologijā šādā veidā bez problēmām apvieno ar konservatīvu jeb, kā viņš pats to nosauc, ortodoksu kristīgu

${ }_{43}$ Michael J. Murray and Andrew Goldberg, "Evolutionary Accounts of Religion: Explaining and Explaining Away," in The Believing Primate: Scientific, Philosophical, and Theological Reflections on the Origin of Religion, eds. Jeffrey Schloss and Michael Murray (Oxford: Oxford University Press, 2009), 198.

${ }_{44}$ Lai gan jāatzīst, ka šādas stratēǵijas piemērošana reliǵijas rašanās kognitīvajiem faktoriem izraisa teismam daudz grūtākas logiskās problēmas nekā pielāgošanās evolūcijai. Skat.: John Teehan, "Cognitive Science and the Limits of Theology," in The Roots of Religion: Exploring the Cognitive Science of Religion, eds. Roger Trigg and Justin L. Barrett (Burlington, VT: Ashgate, 2014), 173-185. 
ticību. ${ }^{45}$ Pēc Bareta domām, kaut arī cilvēka kognitīvie mehānismi saskarsmei ar Dievu ir bojāti, pateicoties grēkam, Dievs nepadodas un atklāj sevi "dažādos veidos, kas aktivizē šīs kognitīvās spējas nojaust pārcilvēciska agenta darbību". ${ }^{46}$ Tā Baretam ir "kognitīvās religijijas zinātnes kristīgā versija". ${ }_{47}$

Ja nav pietiekami pārsteidzoša Bareta un tamlīdzīgi domājošu pētnieku pieeja relig̣iskās ticības savietošanā ar KRZ, tad varam iet vēl tālāk. Izrādās, ka var arī "apgriezt galdus otrādi" un darìt ar KRZ datiem tieši pretējo - izmantot tos, lai attīstītu argumentāciju, kas atbalsta teismu. Tā dara Metjū Bredoks (Matthew Braddock) ${ }^{48}$ nesen iznākušā rakstu krājumā. ${ }^{49}$ Bredoks piedāvā evidenciālu argumentu par labu teismam..$^{50}$ Viņš demonstrē, ka, ņemot vērā cilvēka kognitīvo noslieci uz pārdabisko saskaņā ar KRZ standarta model̦a teorijām, teisms izrādās ticamāks nekā naturālisms. Arguments noved pie secinājuma, ka š̄ nosliece uz pārdabisko ir pārsteidzošāka un mazāk ticama drīzāk naturālisma nekā teisma gadījumā un tādējādi kalpo kā evidence par labu teismam un pret naturālismu.

\section{Nobeiguma pārdomas}

Šim rakstam atvēlētā apjoma ietvaros nav iespējams aptvert visus argumentus. Protams, ateistiski ievirzìtiem religijas filozofiem un KRZ pārstāvjiem būs pretargumentu arsenāls pret viņiem adresētajiem pretargumentiem, uz ko savukārt atbildēs teisti, un tā tas varētu turpināties ad infinitum. Jautājums

${ }_{45}$ Justin L. Barrett, "Cognitive Science, Religion, and Theology," in The Believing Primate: Scientific, Philosophical, and Theological Reflections on the Origin of Religion, eds. Jeffrey Schloss and Michael Murray (Oxford: Oxford University Press, 2009), 77.

46 Ibid., 98.

47 Ibid.

${ }_{48}$ Var piebilst, ka šis pats autors ir attīstījis arī reliğiju "atmaskojošos" argumentus, iespējams, pats būdams reliğiski neitrāls.

49 Matthew Braddock, "An Evidential Argument for Theism from the Cognitive Science of Religion," in New Developments in the Cognitive Science of Religion: The Rationality of Religious Belief, eds. Hans van Eyghen, Rik Peels and Gijsbert van den Brink (Cham, Switzerland: Sringer, 2018), 171-198.

50 Evidenciālie argumenti izsecina varbūtību no evidences. No šì tipa argumentiem reliğijas filozofijā visplašāk pazīstams ir antiteistiskais evidenciālais l̦aunuma eksistences arguments. 
ir - vai ir produktīvi un lietderīgi šādā veidā turpināt? Neizskatās, ka iesaistītās puses kaut mazākā mērā ņemtu vērā otras puses argumentus. Debates nonākušas strupcel̦ā. Log̣iskie argumenti izrādās neefektīvi un, kā izskatās, nepaveic neko citu, kā tikai tālāk nostiprina katras puses attiecīgo "ticību" vai arī skepticismu - gadījumos, kad argumentēts tiek tikai "sporta" pēc.

Tomēr skepticisms var būt arī atbilstīga attieksme religisiskās zināšanas gadījumā. N̦emot vērā kognitīvos ierobežojumus, ko nosaka pats fakts, ka mūsu prāts tapis dabiskos un sociālos apstākḷos, varbūt jāatzīst, ka mēs īsto patiesību nezinām un ar prātu arī nekad nevarēsim zināt. Ja mums būtu "Dieva prāts", varbūt izrādītos, ka maldīgi ir gan KRZ, gan teistiskie pieņēmumi.

Neitrālam vērotājam KRZ pieņēmumi var izskatīties vairāk ticami, vismaz salīdzinājumā ar reliǵiskajām ticības pārliecībām, kas bieži vien ir iracionālas, absurdas, ja tās analizē racionāli. Taču ticīgajiem ir savi "iekšejjie" iemesli - arī ticēt tieši iracionālajam. Ticīgā skatījumā "no iekšienes" relig̣ijai ir sakars ar augstāko realitāti, ko trivializē reliğijas reduktīvie, naturālistiskie izskaidrojumi ar kognitīvajiem mehānismiem cilvēkā, ar evolūcijas blakusproduktiem, ar funkcionālo lietderību, ar prosociālajiem labumiem utt. Visi šie faktori ir niecīgi salīdzinājumā ar šo augstāko realitāti. Vai ir taisnīgi no lielākās daḷas KRZ pārstāvju puses neņemt vērā relig̣ijas būtisko, saturisko izpratni no pašu ticīgo perspektīvas?

Vēl var uzdot jautājumu - vai KRZ praktizètais parsimonijas jeb vienkāršākā izskaidrojuma princips tik tiešām ir piemērots, kad jāskaidro tik komplekss, dažāds un daudzšķautņains fenomens kā relig̣ija? Kā dibināti norāda Luiss Oviedo, "parsimonijas likumu, kas bieži iedvesmo KRZ programmas, diez vai var piemērot, kad jāpēta cilvēciski un sociāli aspekti, kur iesaistīti ļoti daudz faktoru" ${ }^{51} \mathrm{KRZ}$ izpēte bieži vien pārāk vienpusīgi koncentrējas uz religisiskās pārliecības veidojošajiem biolog̣iskajiem, evolucionārajiem, ġenētiskajiem, neirofiziolog̣iskajiem u. tml. faktoriem, tan̄̄ pašā laikā bieži vien ignorējot

${ }_{51}$ Lluis Oviedo, "Explanatory Limits in the Cognitive Science of Religion: Theoretical Matrix and Evidence Levels," in New Developments in the Cognitive Science of Religion: The Rationality of Religious Belief, 31. 
citus faktorus, kuriem bijusi un ir ne mazāka loma religijias daudzveidīgā fenomena vēsturiskajā attīstībā un mūsdienu izpausmēs. Relig̣ija nevar būt arī bez tādiem faktoriem, kas saistās it īpaši ar kultūru - ar vērtību, simbolu, nozīmes un jēgu sistēmām, ar estētiku u. tml.

No otras puses, runājot par "Okama nazi”, varbūt tas tomēr ir jāņem talkā - tikai šoreiz to pavēršot jau pret pašām KRZ religijas teorijām. Cik zinātniskas tās ir? Kāds ir to empīriski un eksperimentāli pamatotas evidences un spekulāciju, fantāzijas lidojumu īpatsvars? Cik daudz no šo teoriju piedāvātajām atziṇām vienkārši jāpieņem "ticībā"? Cik no tām (kā HADD, ToM, mēmu u. c. koncepcijas) vispār iespējams pakḷaut zinātnē pieñemtajam Popera falsifikācijas testam, lai tās vispār varētu uzskatīt par zinātniskām hipotēzēm? ${ }^{52}$

Lai vai kā, ar šìm nobeiguma pārdomām gribu norādīt uz vajadzību pārnest komunikāciju starp abām debatētāju pusēm reliǵijas pamatotības sakarā uz citu līmeni, izejot no nebeidzamo loǵisko atspēkojumu strupcel̦a, arī saredzot un pārvarot savus ideolog̣iskos aizspriedumus. Auglīgāka pieeja varētu būt konstruktīvs dialogs. Teistus varētu mudināt pozitīvāk attiekties pret KRZ vērtīgo pienesumu, kas palīdz apzināt religisisko pārliecību veidojošos kognitīvos un sociobiologiskos faktorus, bet naturālistiski ievirzītus KRZ pārstāvjus varētu aicināt kritiski paskatīties uz reduktīvismu un paplašināt savu reliǵijas pētniecības apvārsni, iesaistot zināšanas no kultūras studijām, relig̣ijas filozofijas, teolog̣ijas u. c. humanitārām jomām, kas interpretē reliǵiju plašāk.

52 Falsifikācijas principu zinātnē 20. gs. vidū ievieš Karls Popers. Saskaṇā ar šo principu hipotēzi var uzskatīt par zinātnisku tikai tad, ja tā spēj pastāvēt pret mēǵinājumiem to apgāzt. Ja vispār nav iespējams nodrošināt apstākḷus, kā hipotēzi pakḷaut šādam falsifikācijas testam, kā tas ir dažādu spekulatīvu teoriju gadījumā, tad hipotēzi nevar uzskatīt par zinātnisku (neskatoties uz to, ka tā varētu būt patiesa vai vismaz heiristiski noderīga). 
Summary

\section{Cognitive Science of Religion and Debates regarding Justification of Religious Beliefs}

Since the last decades of the $20^{\text {th }}$ century we have been witnessing the emergence of a new 'paradigm' or a new 'standard model' of understanding religion as explained by the new multidisciplinary cognitive sciences and a branch known as the cognitive science of religion (CSR). The findings of CSR have extensively been used for debunking religious beliefs. Theologians and philosophers of religion in turn have responded to these debunking attempts. The debates still go on. This paper (1) outlines some typical CSR conceptions of cognitive mechanisms involved in the formation of religious beliefs (such cognitive mechanisms as epidemiology of ideas, memes, hypersensitive agency detection device, theory of mind mechanism, common-sense dualism, minimally counterintuitive ideas, and others, and such prosocial mechanisms as costly signalling, protection against cheaters, and others), (2) lists some typical formalised religion-debunking arguments derived from cognitive theories of religion, (3) gives examples of religion-/theism-friendly counterarguments and (4) in conclusion shows the impasse of logical refutative argumentation between the involved parties and suggests transposing this communication to a different level, instead engaging in a constructive dialogue. 